\title{
Autoimmune disease and gender: Plausible mechanisms for the female predominance of autoimmunity
}

\author{
Olga L. Quintero, Manuel J. Amador-Patarroyo, Gladys Montoya-Ortiz, Adriana Rojas-Villarraga, \\ Juan-Manuel Anaya* \\ Center for Autoimmune Diseases Research (CREA), School of Medicine and Health Sciences, Universidad del Rosario, Carrera 24 \#63-C-69, Bogota, Colombia
}

\section{A R T I C L E I N F O}

\section{Article history:}

Received 21 October 2011

Accepted 24 October 2011

\section{Keywords:}

Autoimmune diseases

Sex hormones

$\mathrm{X}$ chromosome

Gender differences

\begin{abstract}
A B S T R A C T
A large number of autoimmune diseases (ADs) are more prevalent in women. The more frequent the AD and the later it appears, the more women are affected. Many ideas mainly based on hormonal and genetic factors that influence the autoimmune systems of females and males differently, have been proposed to explain this predominance. These hypotheses have gained credence mostly because many of these diseases appear or fluctuate when there are hormonal changes such as in late adolescence and pregnancy. Differences in X chromosome characteristics between men and women with an AD have led researchers to think that the genetic background of this group of diseases also relates to the genetic determinants of gender. These hormonal changes as well as the genetic factors that could explain why women are more prone to develop ADs are herein reviewed.
\end{abstract}

(c) 2011 Elsevier Ltd. All rights reserved.

\section{Introduction}

Almost $5 \%$ of the world population develops an AD. Of this $5 \%$ approximately $78 \%$ are women [1] and it is considered the fourth leading cause of disability for them [2]. Women are at 2.7 times greater risk of acquiring an $\mathrm{AD}$ than men [3]. The rate between women and men in the most prevalent $A D$ may vary from 9:1 in systemic lupus erythematosus (SLE), autoimmune thyroid disease (AITD) and Sjögren's syndrome (SS) to 3:1 in rheumatoid arthritis (RA) and multiple sclerosis (MS) [4-7]. Also, female gender appears to be a risk factor for polyautoimmunity (i.e., more than one AD coexisting in a single patient) [8]. Women tend to have a different age at onset and different disease activity than men. Onset in women is generally observed in the reproductive ages and coincides with the moment when the hormone levels begin to rise. Two good examples are MS and SLE in which women have an early onset. In contrast, men have a late onset which is associated with an increased prevalence of complications. A few disorders like spondyloarthropathies are more common in men [2]. This supports the idea that woman are more prepared evolution-wise to pay the immunological price for the reproductive benefit than men. Fig. 1 depicts the mechanisms that have been proposed to explain the

\footnotetext{
* Corresponding author. Tel.: +571 3499650; fax: +571 3499340.

E-mail address: anayajm@gmail.com (J.-M. Anaya).
}

susceptibility of women to ADs, and which will be addressed in this review.

\section{Hormones and immune system}

Generally, women have a stronger humoral and cellular immune response compared to men. They show a higher CD4:CD8 ratio because of a higher absolute CD4 cell count and a higher level of circulating antibodies [9]. Compared to men, they have more rapid rejection of allograft and reduced incidence and regression of tumors [10].

Estrogens, androgens and prolactin are hormones that have been studied for increasing susceptibility to ADs and can affect both innate and adaptive immune systems $[2,11,12]$. Estrogens seem to direct the immune system to T-helper 2 (Th2) lymphocyte dominance with the consequence of more $B$ cell activation and antibody production [13]. In contrast, androgen favors the development of a T-helper 1 (Th1) response and CD8+ cell activation [14,15]. Prolactin appears to stimulate both cell and humoral-based immunity [16]. For this modulation of the immune system to be possible, these hormones have to be able to bind to receptors expressed by immune cells. B cells have been shown to express both androgen and estrogen receptors. In murine models, CD8 cells have been shown to express estrogen receptors along with monocytes, neutrophils and natural killer cells $[5,17,18]$. Other studies suggest that sex hormones like estrogen can regulate 


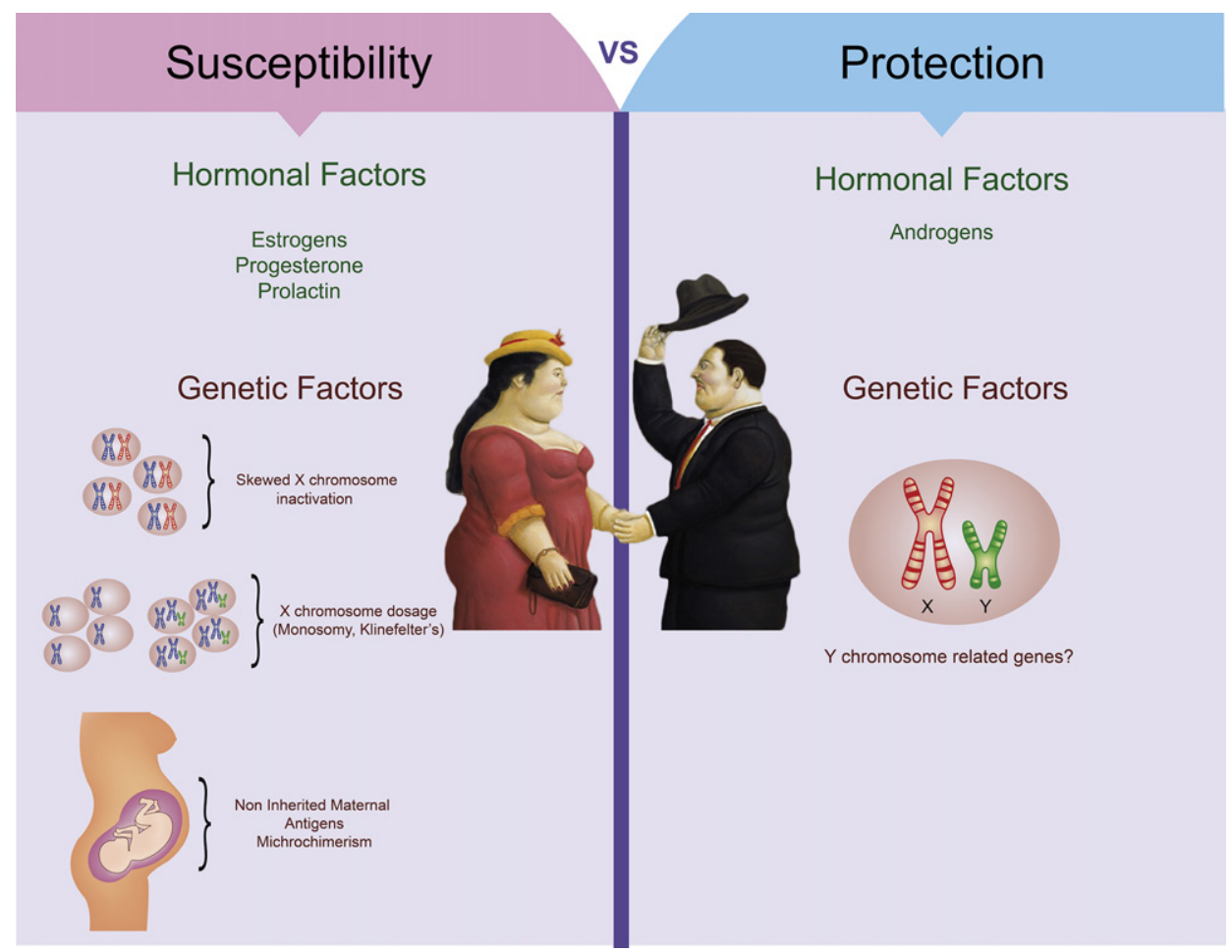

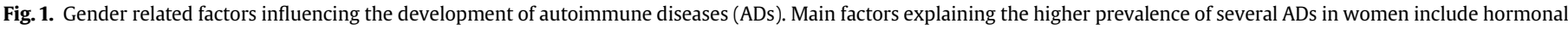

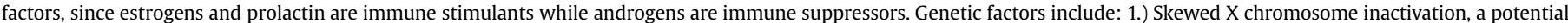

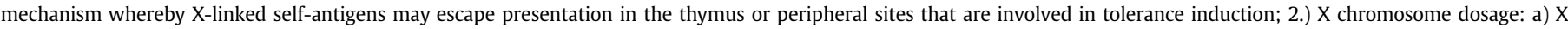

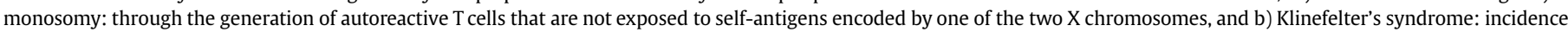

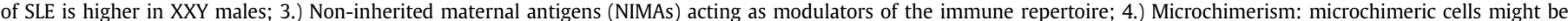

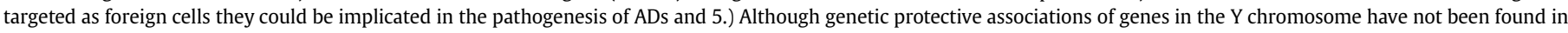
humans, rodent models suggest that unexplored regions or genes in the Y chromosome may play a role in the protection of men to the most relevant ADs.

antigen presentation by macrophages and dendritic cells through production of transforming growth factor beta $[19,20]$.

\section{Hormones and autoimmune diseases}

\subsection{Systemic lupus erythematosus}

SLE has a significant predominance in women. It tends to worsen during pregnancy and to remit after menopause. This suggests that sex hormones are crucial for SLE regulation [21,22]. Estrogen and prolactin act as immune-stimulators by affecting maturation and selection of autoreactive B cells and autoantibody secretion $[23,24]$. About $22-33 \%$ of SLE patients have mild to severe hyperprolactinemia [25]. Gutierrez et al. showed that unstimulated peripheral blood monocytes in SLE patients produce more prolactin than they do in healthy patients [26]. Prolactin leads to the production of interferon-gamma which is an important mediator in lupus nephritis [27]. Bromocriptine, an inhibitor of prolactin secretion, has shown beneficial effects in both murines and humans [28]. An imbalance between hormone relationships can result in lower immune-suppressive androgens and higher immunoenhancing estrogens. Women with SLE tend to have lower androgen levels than healthy women [29]. Likewise, men with the disease have elevated serum levels of 16-hydroxyestrone and estrone causing an imbalance between these hormones. Some of them have hypoandrogenism, low levels of testosterone and elevated levels of luteinizing hormone $[22,30]$. Testosterone is thought to suppress anti-double stranded DNA antibody production [22].

\subsection{Sjögren's syndrome}

This disease is also one of the most prevalent ADs among women. Verheul et al. studied the effect of gender hormone predominance by doing a gonadectomy on the non-obese diabetic (NOD) mouse, an accepted SS model [31]. This caused a worsening of the disease but the use of additional estrogen doses did not change the outcome of the disease. This may suggest a stronger protective effect on the part of androgens than a vulnerability because of estrogens $[22,31]$. SS primarily affects women during the fourth and fifth decades of life, with a woman:man ratio of 9:1 [32]. In men SS is uncommon. Since there are few reports on the clinical and immunological differences of SS, each one of them with small sample sizes, we wanted to combine the results of those reports in order to find differences between males and females with statistical significance.

Publications were identified through a systematic search done by two independent experts in Pubmed using the [Mesh] terms "Sjögren's syndrome" and "men". The only limit applied was "title". Descriptive statistics were used to define the subject's characteristics. Categorical variables were compared using the chi ${ }^{2}$ test. Results under $p=0.05$ were considered as statistically significant. The odds ratio (OR) was calculated for assessing the risk of appearance of each variable, with a confidence interval (CI) of $95 \%$.

According to all the cases published so far (Tables 1 and 2) women with SS have more anti-Ro antibodies and Raynaud's phenomenon than men. Conversely, men with SS are at higher risk for lymphoma and neurological involvement than women. Accordingly, male gender should be considered as a new risk factor for lymphoma development in patients with SS [33,34]. 


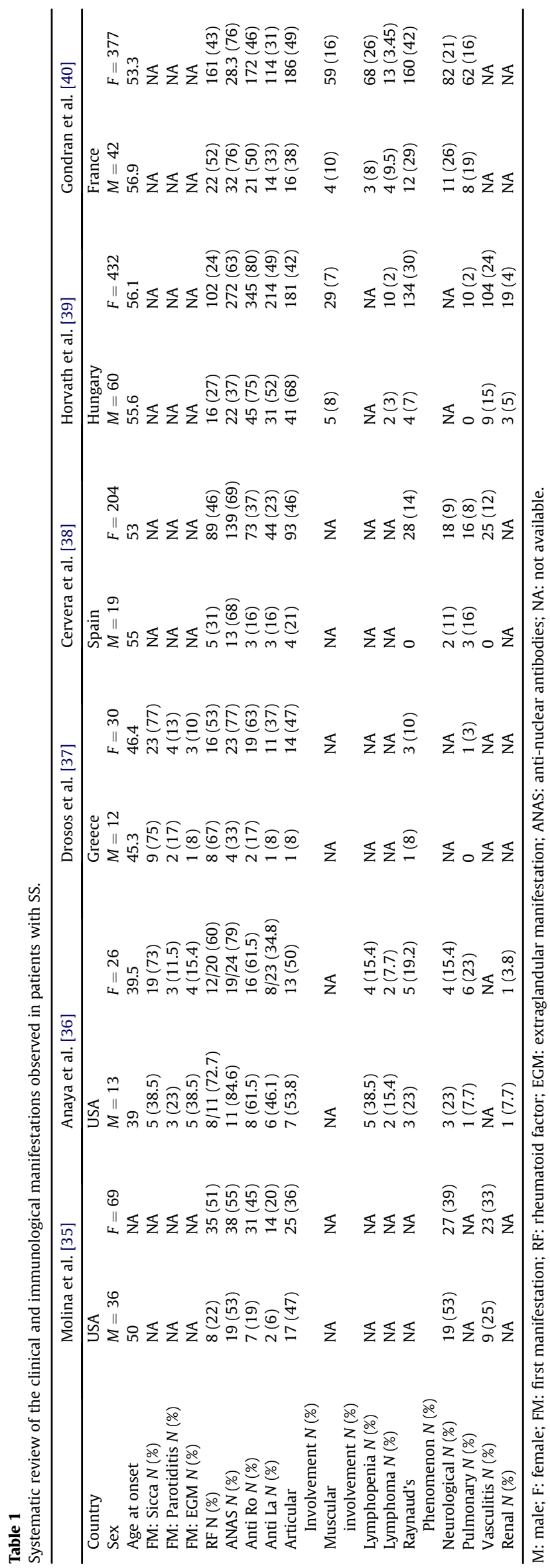

\subsection{Rheumatoid arthritis}

Similar hormone imbalances in RA have been shown in many studies. Synovial fluid levels of estrogens relative to androgens are significantly elevated in both male and female RA patients and have activation effects on macrophage and fibroblast proliferation $[41,42]$. The treatment with tumor necrosis factor- $\alpha$ (TNF- $\alpha$ ) blockers affects hormone levels in the synovial fluid before affecting the serum levels and seems to block the conversion from androgens to estrogens induced by aromatase $[43,44]$.

Active RA is characterized by an activity peak early in the morning and correlated with prolactin plasma levels observed at that time [45]. A decreased amount of serum androgens has also been associated with disease susceptibility [46]. Men with the disease show low serum levels of testosterone as well as dehydroepiandrosterone [47]. This data is consistent with the hypothesis that androgens are anti-inflammatory hormones [48].

\subsection{Systemic sclerosis (SSc)}

This disorder is a polymorphic and heterogenic systemic disorder with inflammation, fibrosis and vascular damage. It has a $3: 1$ woman to man ratio $[49,50]$. Shi-Wne et al. showed that estrogens could induce fibroblast dysfunction in SSc and the female predisposition to the disease [51]. Straub et al. demonstrated that the association between high prolactin and low DHEA serum levels was an important factor for increased SSc severity [52].

\subsection{Multiple sclerosis}

Evidence indicates that gender affects the susceptibility and course of MS with a higher prevalence and better prognosis in woman than men. The improvement in the disease during late pregnancy has also been linked to hormonal changes. The disease itself can affect the levels of sex steroids by damaging hypothalamic regions and causing dysfunction of the hypothalamo-pituitary-gonadal axis [53]. In MS patients, prolactin secretion could rise [54]. Meanwhile, male MS patients may have low testosterone levels and higher estradiol levels and these findings are associated with a greater degree of brain tissue damage [55]. Table 3 summarizes hormonal influences and clinical findings in ADs.

\subsection{Pregnancy}

Pregnancy results in changes in disease activity for some of the autoimmune disorders. Signs and symptoms of MS and RA lessen during pregnancy and postpartum may be associated with disease exacerbation. Meanwhile, SLE is often exacerbated during pregnancy [62] and disease activity is associated with a worse fetal outcome $[63,64]$.

Pregnancy may induce changes in the maternal immune system in order to protect the fetus. A shift from the prevailing Th1 response to a type Th2 could be seen and attributed to an increased progesterone level $[65,66]$. Also, pregnant women have enhanced immunoglobulin production and an increased production of autoantibodies [10,67].

A worse pregnancy outcome has been found in SLE patients, with glomerulonephritis being the main disease manifestation threatening both maternal and fetal health $[63,68]$. Imbasciati et al. showed that normocomplementemia and low dose aspirin therapy during pregnancy were independent predictors of a favorable fetal outcome. Experts support the idea that pregnancy can start only if the disease is inactive and close monitoring must be done [69]. 
Table 2

Meta-analysis of clinical and immunological manifestations in male patients with SS as compared with female patients.

\begin{tabular}{|c|c|c|c|c|c|c|c|}
\hline & Men $^{\mathrm{a}}$ & Women $^{\mathrm{a}}$ & $N$ & Chi & $P$ value & OR & $95 \% \mathrm{CI}$ \\
\hline Age at onset (Years, Mean \pm SD) & $50.3 \pm 7$ & $49.6 \pm 6.7$ & & & & & \\
\hline FM:Sicca & $14(56)$ & $42(75)$ & $56 / 81$ & 2.92 & 0.08 & 0.42 & $(0.14-1.28)$ \\
\hline FM:Parotiditis & $5(20)$ & $7(12.5)$ & $12 / 81$ & 0.77 & 0.38 & 1.75 & $(0.42-7.19)$ \\
\hline FM:EGM & $6(24)$ & $7(12.5)$ & $13 / 81$ & 1.71 & 0.19 & 2.21 & $(0.56-8.66)$ \\
\hline $\mathrm{RF}$ & $67(36)$ & $415(36.4)$ & $482 / 1320$ & 0.01 & 0.92 & 1.02 & $(0.72-1.42)$ \\
\hline ANAS & $101(55.5)$ & $519(45.6)$ & $620 / 1320$ & 6.16 & 0.013 & 1.49 & $(1.07-2.06)$ \\
\hline Anti Ro & $86(47.3)$ & $656(57.6)$ & $742 / 1320$ & 6.88 & 0.0086 & 0.66 & $(0.48-0.91)$ \\
\hline Anti La & $57(31.3)$ & $405(35.5)$ & $462 / 1320$ & 1.26 & 0.26 & 0.83 & $(0.58-1.17)$ \\
\hline Articular involvement & $86(47.2)$ & $512(44.9)$ & $598 / 1320$ & 0.32 & 0.56 & 1.10 & $(0.79-1.52)$ \\
\hline Muscular involvement & $9(8.8)$ & $88(10.8)$ & $97 / 911$ & 0.40 & 0.52 & 0.79 & $(0.36-1.69)$ \\
\hline Lymphopenia & $8(14.5)$ & $72(17.8)$ & $80 / 458$ & 0.37 & 0.54 & 0.78 & $(0.33-1.81)$ \\
\hline Lymphoma & $8(6.9)$ & $25(2.9)$ & $33 / 950$ & 4.73 & 0.029 & 2.42 & $(0.98-5.81)$ \\
\hline Raynaud's Phenomenon & $20(13.6)$ & $330(30.8)$ & $350 / 1215$ & 18.47 & 0.00001 & 0.36 & $(0.21-0.59)$ \\
\hline Neurological & $35(31.8)$ & $131(19.3)$ & $166 / 786$ & 8.79 & 0.003 & 1.94 & $(1.21-3.10)$ \\
\hline Pulmonary & $12(8.2)$ & $95(8.8)$ & $107 / 1215$ & 0.07 & 0.78 & 0.92 & $(0.47-1.77)$ \\
\hline Vasculitis & $18(15.6)$ & $152(21.5)$ & $170 / 820$ & 2.10 & 0.14 & 0.68 & $(0.38-1.18)$ \\
\hline Renal & $4(5.4)$ & $20(4.3)$ & $24 / 531$ & 0.18 & 0.67 & 1.27 & $(0.36-4.09)$ \\
\hline
\end{tabular}

FM: first manifestation; EGM: extraglandular manifestation; ANAS: anti-nuclear antibodies; RF: rheumatoid factor; OR: odds ratio; CI: confidence interval.

a Data correspond to numbers (percentage) except if indicated otherwise.

The improvement of MS and RA during pregnancy may be linked to the transition from Th1 response to a Th2 state. Postpartum worsening may be associated with the return to the Th1 environment [10]. After pregnancy, a flare may be induced in RA by breastfeeding through the actions of prolactin [70]. Several studies have confirmed the spontaneous improvement of RA during pregnancy and an increased risk of flare after delivery. The decreased RA activity during pregnancy may well be the net result of complex pregnancy-related hormonal and immunological alterations. In fact, the increased levels of cortisol, estrogen and vitamin $\mathrm{D}$ have been implicated in lowering the pro-inflammatory cytokines, interleukin-12 and TNF- $\alpha$, during pregnancy. This improvement in symptoms occurs predominantly in the third trimester when estrogen and progesterone are at their peak $[64,71]$. Pregnancy does not appear to cause disease deterioration in patients with SSc $[2,64]$. Table 4 addresses the effects of pregnancy in patients with different ADs.

\subsection{Other hormonal influences}

Changes in the disease severity during menses, menopause and hormonal contraceptive use are also described. In young patients, an early age at menarche has been associated with doubling the risk of SLE and RA [73,74]. Also the worsening of symptoms in RA, SLE and MS has been reported prior to the onset of menses [74,75]. In older women, RA has a high incidence at menopause [77] while onset of SLE is less common in postmenopausal women [10,78]. The use of oral contraceptives in MS is associated with a decrease in disease incidence $[6,79]$. In SLE, their use is associated with disease exacerbation [80] and the safety of estrogens in lupus

Table 3

Hormonal influences and clinical findings in autoimmune diseases.

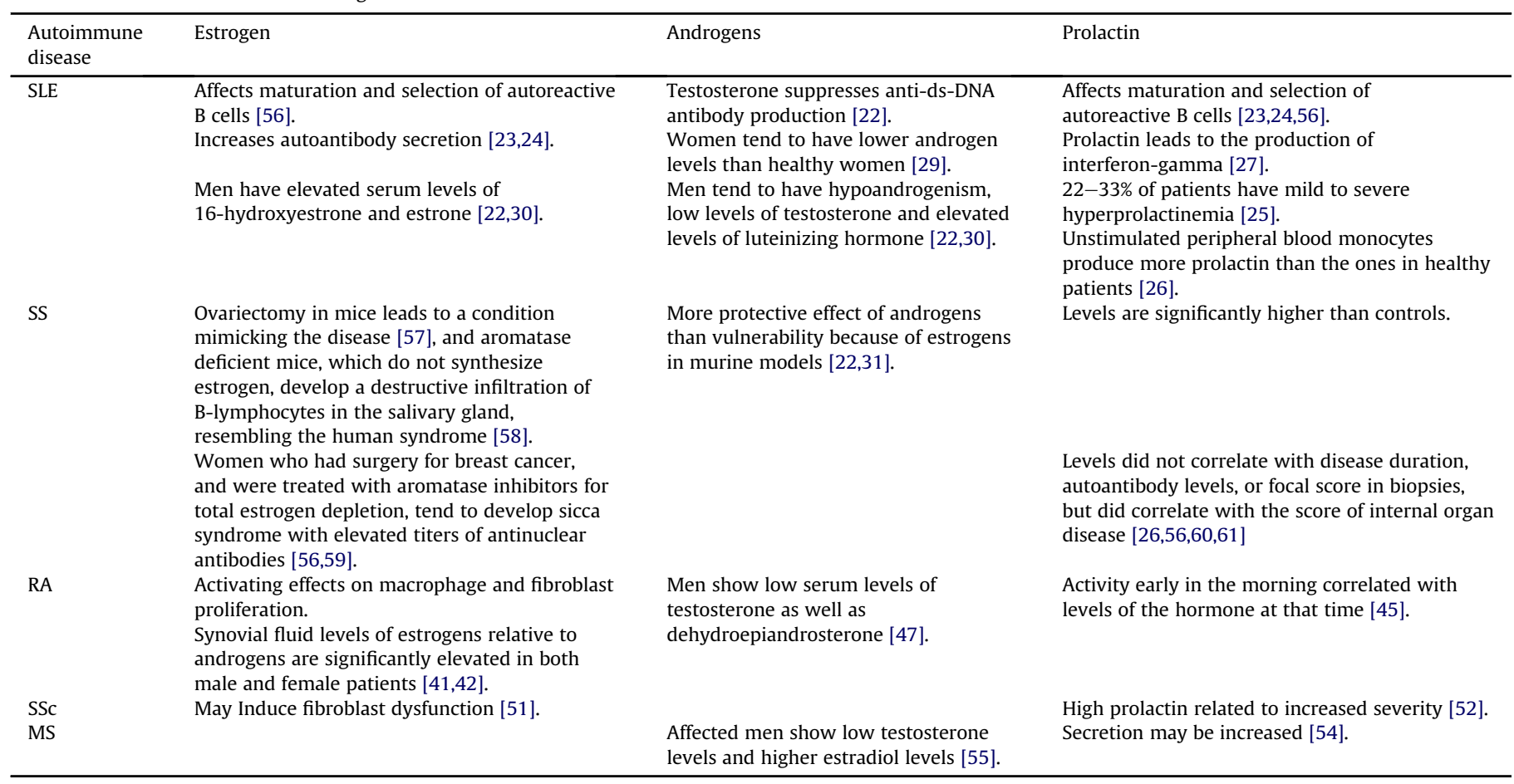


Table 4

Autoimmune diseases and pregnancy.

\begin{tabular}{|c|c|c|c|c|}
\hline $\begin{array}{l}\text { Systemic lupus } \\
\text { erythematosus }\end{array}$ & $\begin{array}{l}\text { Rheumatoid } \\
\text { arthritis }\end{array}$ & Multiple sclerosis & Systemic sclerosis & Sjögren's syndrome \\
\hline $\begin{array}{l}\text { Often exacerbates during } \\
\text { pregnancy [62]. } \\
\text { Disease activity has been } \\
\text { associated with a worse } \\
\text { pregnancy outcome[63]. }\end{array}$ & $\begin{array}{l}\text { Often improves during pregnancy, } \\
\text { especially in the third trimester } \\
\text { when estrogen and progesterone } \\
\text { are at their peak }[10,70] \text {. }\end{array}$ & $\begin{array}{l}\text { Often Improves during pregnancy, } \\
\text { especially in the third trimester } \\
\text { when estrogen and progesterone } \\
\text { are at their peak }[10,70] \text {. }\end{array}$ & $\begin{array}{l}\text { Pregnancy does not } \\
\text { appear to cause disease } \\
\text { deterioration [2]. }\end{array}$ & $\begin{array}{l}\text { Although pregnancy seems to } \\
\text { have a low impact on disease, } \\
\text { there is risk for the offspring to } \\
\text { present neonatal SLE [72]. }\end{array}$ \\
\hline $\begin{array}{l}\text { Glomerulonephritis is the main } \\
\text { concern. }\end{array}$ & $\begin{array}{l}\text { Flares may be induced } \\
\text { by breastfeeding through } \\
\text { the action of prolactin [70]. }\end{array}$ & & & \\
\hline
\end{tabular}

SLE: systemic lupus erythematosus.

erythematosus national assessment (SELENA) study shows that hormone replacement therapy with estrogens can induce mild exacerbations [81].

\section{Genetic factors}

It is well known that females and males are different in their basic immune response with most of the evidence gathered from work done on rodents [4]. Female rodents have a more vigorous response after immunization than males and produce higher levels of antibodies and activated T lymphocytes. In the case of humans, it has not been possible to duplicate these results with most investigations yielding conflicting conclusions $[4,82]$. However, women are known to have higher levels of circulating antibodies, absolute counts of CD4+ T lymphocytes and higher production of cytokines and antibodies in response to infection $[18,76,82,83]$. Not only do women and men differ in their normal immune response but there are also differences between them in the prevalence, presentation and severity of ADs. This leads to the notion that increased immune function imparts increased susceptibility to autoimmunity in women $[2,18,84,85]$. There are multiple hypotheses about the genetic mechanisms that could explain the sex bias in ADs. Nevertheless, the exact pathways are largely unexplored and are still far from being clearly understood.

\subsection{X chromosome inactivation}

Unlike the gene-poor $\mathrm{Y}$ chromosome, the $\mathrm{X}$ chromosome contains over 1000 genes that are essential for proper development and cell viability. However, females carry two copies of the $\mathrm{X}$ chromosome, resulting in a double dose of X-linked genes. To correct this imbalance, mammalian females have evolved a unique epigenetic mechanism of dosage compensation: the X chromosome inactivation. Female mammals transcriptionally silence one of their two X chromosomes in a random, complex and highly coordinated manner early in embryogenesis [86]. The inactivated X chromosome then condenses into a compact structure called the Barr body, and it is stably maintained in a silent state. In theory, this process should be sufficient to establish equal expression of genes on the $\mathrm{X}$ chromosome in female and male cells. Notwithstanding, it is now known that under physiological conditions, the $\mathrm{X}$ chromosome is only partially inactivated and about $10-15 \%$ of the genes may be expressed by both $\mathrm{X}$ chromosomes in female cells $[12,18,84]$. Thus, females are functional mosaics for the $\mathrm{X}$-linked genes.

The $\mathrm{X}$ chromosome inactivation is generally random in somatic tissue and once chosen, the inactivation is kept stable and the same chromosome is inactivated in all progeny cells. However, in many cases the inactivation may be skewed for stochastic reasons or because of severe mutations [87]. Despite the inactivation of the $\mathrm{X}$ chromosomes being random or non-random, the pattern within an individual is dynamic during life and older females may manifest a skewed pattern as an acquired trait that is not pathogenic by itself [88].

Skewed X chromosome inactivation happens when one of the two alleles (either from the mother or the father) is in the active $\mathrm{X}$ chromosome in more than $75 \%$ of cells [87]. Skewing of $X$ chromosome inactivation is expressed as a percentage deviation from equal inactivation (50:50) of the alleles. Extreme skewing is defined as a greater than $40 \%$ deviation from a $50: 50$ distribution (one of the two alleles in the active X chromosome in $\geq 90 \%$ of cells) $[89,90]$. It has been noted that skewed inactivation is more prevalent in patients with ADs than in healthy controls [2,84,90-92].

It is well known that ADs are the result of the loss of immunological tolerance to self-antigens, therefore, the process of $\mathrm{X}$ chromosome inactivation offers a potential mechanism whereby Xlinked self-antigens may escape presentation in the thymus or in other peripheral sites that are involved in tolerance induction [89]. Although the exact mechanisms that cause X chromosome inactivation are still speculative, in theory, this could result in a situation in which self-antigens on one $\mathrm{X}$ chromosome may fail to be expressed at sufficiently high levels in compartments such as the thymus, and yet may be expressed at considerable frequency in peripheral tissues. This could be the stimuli necessary to break the tolerance of the immune system and lead to the development of autoreactive T lymphocytes [89]. Another important aspect of extremely skewed X chromosome inactivation is that it does not lead to the breakdown of self tolerance in all females. This means that there must be a second event to break down self tolerance: a mutation leading to loss of mosaicism, and second, heterozygosity for the non-synonymous variants of the putative critical genes [91].

Another hypothetical mechanism could be that skewed $\mathrm{X}$ chromosome inactivation could lead to the inactivation of a gene that protects against autoimmunity, or over-expression of a susceptibility gene thus leading to increased AD [84]. Table 5 summarizes case-control reports that evaluated the patterns of $\mathrm{X}$ chromosome inactivation in patients with ADs.

The inconsistencies found in some reports that fail to demonstrate a significant difference between the patterns of inactivation of patients compared to controls may be due to differences in etiology, pathophysiology and unknown mechanisms by means of which skewed $X$ chromosome inactivation may influence female biased autoimmunity $[89,99]$. Also, age differences, sample sizes, different definitions of cut-off points for skewed $\mathrm{X}$ inactivation might explain the discrepancies. Likewise, the possibility that tissues other than blood would be more appropriate for finding a significant difference in skewed $\mathrm{X}$ chromosome inactivation patterns has to be considered $[89,99]$.

\subsection{X chromosome dosage}

\subsubsection{X chromosome monosomy}

Another mechanism that has been proposed to explain female biased autoimmunity is the $\mathrm{X}$ chromosome monosomy based on 


\begin{tabular}{|c|c|c|c|c|c|c|}
\hline Ref. & Year & $\mathrm{AD}(n)$ & $n$ (patients/controls) & $\begin{array}{l}\%(n) \text { skewed inactivation } \\
\text { in informative patients }\end{array}$ & $\begin{array}{l}\text { Significant Skewed } \\
\text { X-Chromosome inactivation }\end{array}$ & Comments \\
\hline \multirow[t]{5}{*}{$\begin{array}{l}\text { Chitnis } \\
\text { et al. }{ }^{\mathrm{a}}[89]\end{array}$} & 2000 & $\mathrm{JD}(45)$ & $167 / 30$ & JD: 13.7 & No & $\begin{array}{l}\text { Effect of skewing depends on the pattern } \\
\text { of inactivation in selected tissues (differences } \\
\text { in X inactivation patterns between oral mucosa } \\
\text { (ectoderm) and peripheral blood (mesoderm) } \\
\text { in the same individual) }\end{array}$ \\
\hline & & MS (58) & & MS: 19.52 & & Sample size for each AD might have been too \\
\hline & & SLE (46) & & SLE: 13.7 & & small to find significant differences. \\
\hline & & JIA (18) & & JIA: 13.73 & & \\
\hline & 2004 & SSc & 70/160 (Informative: & $\begin{array}{l}\text { Controls: } 17.9 \\
\text { SSc: } 64 \text { (35) }\end{array}$ & Yes $(p<0.0001)$ & Skewed X chromosome inactivation does not \\
\hline \multirow{2}{*}{$\begin{array}{l}\text { Özbalkan } \\
\text { et al. [92] }\end{array}$} & 2007 & 30 & $55 / 124)$ & & $103(P<-0.0001)$ & $\begin{array}{l}\text { lead to development of SSc in all women; } \\
\text { therefore a subsequent event must be necessary } \\
\text { to break down self tolerance. }\end{array}$ \\
\hline & & & & Controls: 8 (10) & & $\begin{array}{l}\text { Random pattern of } X \text { chromosome inactivation } \\
\text { in skin, oral mucosa and hair follicle samples } \\
\text { was observed. }\end{array}$ \\
\hline $\begin{array}{l}\text { Ozcelik } \\
\text { et al. [93] }\end{array}$ & 2005 & $\begin{array}{l}\text { AITD (HT: } \\
\text { 89, GD: } 29)\end{array}$ & $\begin{array}{l}\text { 110/160 (Informative: } \\
\text { 83/124 [HT: 67; GD: 16]) }\end{array}$ & $\begin{array}{l}\text { AITD: } 34(28) \\
\text { [HT: } 34.3(23) ; \\
\text { GD: } 31(5)] \\
\text { Controls: } 8(10)\end{array}$ & Yes $(p>0.0001)$ & $\begin{array}{l}\text { Five randomly selected patients showed skewing } \\
\text { in the same direction for thyroid and oral } \\
\text { mucosa biopsy. }\end{array}$ \\
\hline \multirow[t]{3}{*}{$\begin{array}{l}\text { Brix } \\
\text { et al. [94] }\end{array}$} & 2005 & AITD & $32 / 96$ & $\begin{array}{l}\text { External controls: } \\
\text { AITD: } 34 \text { (11) [HT: } \\
31 \text { (4); GD: } 37 \text { (7)] }\end{array}$ & Yes & Twin case-control study: \\
\hline & & $\begin{array}{l}\text { (HT: } \\
13, \text { GD: 19) }\end{array}$ & & Controls: 11.4 (11) & $\begin{array}{l}\text { (External controls: } \\
p=0.003 ; \text { Within-pair } \\
\text { comparison: } p=0.03 \text { ) }\end{array}$ & $\begin{array}{l}\text { 1. External controls: Twin individuals with AITD } \\
\text { (cases) with matched, unrelated control twin } \\
\text { individuals }\end{array}$ \\
\hline & & & & $\begin{array}{l}\text { Co-Twin comparison: } \\
\text { AITD twins: } 42(11) \\
\text { Healthy twins: } 12(3)\end{array}$ & & $\begin{array}{l}\text { 2. Within-pair comparison: } 26 \text { twin pairs } \\
\text { discordant for AITD: the healthy twin was } \\
\text { the control. }\end{array}$ \\
\hline $\begin{array}{l}\text { Uz } \\
\text { et al. [90] }\end{array}$ & 2007 & SSc & $\begin{array}{l}\text { 125/160 (Informative: } \\
94 / 124)\end{array}$ & $\begin{array}{l}\text { SSc: } 34(32) \\
\text { Controls: } 8(10)\end{array}$ & Yes $(p<0.0001)$ & $\begin{array}{l}\text { Skewed X chromosome inactivation does not } \\
\text { lead to development of SSc in all women; } \\
\text { therefore a subsequent event must be necessary } \\
\text { to break down self tolerance. }\end{array}$ \\
\hline \multirow[t]{2}{*}{$\begin{array}{l}\text { Knudsen } \\
\text { et al. [95] }\end{array}$} & 2007 & $\begin{array}{l}\text { MS (260 RR-MS, } \\
108 \text { SP-MS, } \\
94 \text { PP MS) }\end{array}$ & $\begin{array}{l}\text { 568/132 (Informative: } \\
462 \text { patients) }\end{array}$ & $\begin{array}{l}\text { MS: } 17 \text { (77) [RR-MS: } \\
15 \text { (38); SP-MS: } \\
20 \text { (22); PP-MS: } \\
18 \text { (17)] }\end{array}$ & $\begin{array}{l}\text { No (Patients vs. controls: } \\
p=0.137\end{array}$ & $\begin{array}{l}\text { Post hoc tests with Bonferroni correction showed } \\
\text { no significant differences between the groups. }\end{array}$ \\
\hline & & & & Controls: $11(15)$ & $\begin{array}{l}\text { Comparisons between } \\
\text { groups of MS: } p=0.37 \text { ) }\end{array}$ & $\begin{array}{l}\mathrm{X} \text { chromosome inactivation pattern does not seem } \\
\text { to explain the female predominance observed } \\
\text { in MS in general: PBMC does not reflect real skewing } \\
\text { patterns of other tissues that might be more relevant } \\
\text { in the development of autoimmunity. }\end{array}$ \\
\hline \multirow[t]{2}{*}{$\begin{array}{l}\text { Miozzo } \\
\text { et al. }{ }^{\mathrm{a}, \mathrm{c}}[96]\end{array}$} & 2007 & РBC & $\begin{array}{l}\text { 166/226 (Informative: } \\
\text { 146/195 [Healthy }\end{array}$ & & No & $\begin{array}{l}\text { The study evaluated } X \text { chromosome inactivation } \\
\text { patterns and } X \text { chromosome mononosomy patterns. }\end{array}$ \\
\hline & & & controls: 155, CHC: 40$]$ ) & $\begin{array}{l}\text { CHC: } 47(23) \\
\text { Healthy Controls: } \\
41(72)\end{array}$ & & $\begin{array}{l}\text { A preferential } X \text { chromosome loss independent } \\
\text { of the } X \text { chromosome inactivation pattern was found. }\end{array}$ \\
\hline $\begin{array}{l}\text { Yin } \\
\text { et al. [97] }\end{array}$ & 2007 & $\begin{array}{l}\text { AITD (GD: } 87, \\
\text { HT: 47) }\end{array}$ & $\begin{array}{l}\text { 134/69 (Informative: } \\
\text { 113/58 [GD: 70, HT: 43) }\end{array}$ & $\begin{array}{l}\text { AITD: } 27 \text { (31) [GD: } \\
29 \text { (20) HT: } 26 \text { (11)] }\end{array}$ & Yes $(p=0.004)$ & $\begin{array}{l}\text { There was no correlation of skewed X chromosome } \\
\text { inactivation and age. } \\
\text { There was no correlation between the degree } \\
\text { of skewed X chromosome inactivation and the } \\
\text { age of AITD onset. }\end{array}$ \\
\hline
\end{tabular}


the observed increased incidence of autoimmune disorders in diseases such as Turner's syndrome [100-102]. Furthermore, several reports have found the rate of $\mathrm{X}$ monosomy to be significantly increased in peripheral white blood cells of patients with primary biliary cirrhosis (PBC), AITD and SSc as well as with age $[96,100,103]$. It is also notable that increased $X$ monosomy rates have been found more frequently in peripheral $\mathrm{T}$ and $\mathrm{B}$ lymphocytes than in other blood cell populations without evidence of microchimerism that would explain the existence of the monosomic cells [100-105]. However, these findings could not be duplicated in a study of female patients with SLE, in which the authors proposed that the methylation pattern rather than the monosomy of the $\mathrm{X}$ chromosome, along with other hypotheses, might have a more preponderant role in female biased autoimmunity, but this needs further research [104]. Invernizzi et al. offers an explanation of how $\mathrm{X}$ monosomy might be associated with autoimmunity by hypothesizing that $\mathrm{X}$ chromosome monosomy may cause a haploinsufficiency in X-linked genes that escape $\mathrm{X}$ chromosome inactivation and, as a consequence, autoreactive $\mathrm{T}$ cells are not exposed to self-antigens encoded by one of the two $\mathrm{X}$ chromosomes. Therefore, these autoreactive T cells may be exposed to these self-antigens and react against them with the consequent development and perpetuation of an autoimmune response $[102,105]$. However, it is more likely that X chromosome alterations would generate a negative impact on the immune system homeostasis and this deregulation would affect $\mathrm{B}$ and/or $\mathrm{T}$ lymphocytes directly [102]. Case-control reports evaluating $\mathrm{X}$ chromosome monosomy are summarized in Table 6 .

\subsubsection{Klinefelter's syndrome}

Observations that the incidence of SLE is higher in XXY males (Klinefelter's syndrome) and low in XO females (Turner's syndrome) have pointed towards an $\mathrm{X}$ chromosome gene-dosage effect in female biased autoimmunity. This takes into account not only the monosomy of the X chromosome but also the "over-dose" of it [2]. The first case report of SLE and Klinefelter's syndrome occurring in the same patient was in 1969 by Oritz-Neu et al. [106]. They reported 3 cases with this association. Subsequently, other case reports have surfaced in the literature [107].

In experimental models of mice, Smith-Bouvier et al. found that sex chromosomes contributed to female biased susceptibility to AD. Transgenic SJL mice were created to permit a comparison between $\mathrm{XX}$ and $\mathrm{XY}$ within a common gonadal type (gonadectomized mice) to remove any intercurrent effects of sex hormones that might mask effects of sex chromosomes. Results show that mice that were $\mathrm{XX}$, as compared with the ones that were $\mathrm{XY}$, demonstrated greater susceptibility to both experimental autoimmune encephalomyelitis and pristane-induced lupus [108]. Scofield et al. studied 378 multiplex SLE families with 76 male SLE patients and 138 patients with non-familial SLE and found $a>13$-fold higher prevalence of Klinefelter's syndrome than is found in the general male population $(p<0.001)$ [109]. So far, the stronger association has been found between Klinefelter's syndrome and SLE. The relationship of 47XXY to other ADs needs further investigation.

\subsection{Non-inherited maternal antigens (NIMAs)}

These molecules are defined as antigens in the offspring which are not encoded by the inherited alleles of the offspring but by the mother's alleles and are passed to the offspring through microchimerism. Non-inherited maternal antigens occur when there is maternal-fetal genotype incompatibility [2]. It has been established that some ADs are significantly more frequent in subjects who carry certain HLA antigens. However, not all of the carriers are affected by these entities and likewise, a significant proportion of 
Table 6

Case-Control reports investigating associations of $\mathrm{X}$ chromosome monosomy and autoimmune diseases.

\begin{tabular}{|c|c|c|c|c|c|c|c|}
\hline Ref. & Year & $A D$ & $\begin{array}{l}N \text { (patients/ } \\
\text { controls) }\end{array}$ & $\begin{array}{l}\% \pm \mathrm{SD} \\
\mathrm{X} \text { chromosome } \\
\text { monosomy }\end{array}$ & $\begin{array}{l}\text { Significant } \\
\mathrm{X} \text { chromosome } \\
\text { monosomy }\end{array}$ & Technique & Comments \\
\hline $\begin{array}{l}\text { Invernizzi } \\
\text { et al. [103] }\end{array}$ & 2004 & PBC & $\begin{array}{l}\text { 100/100 } \\
\text { (Controls: CHC: } 50, \\
\text { Healthy: } 50 \text { ) }\end{array}$ & $\begin{array}{l}\text { PBC: } 10.3 \\
{[7.5-14]^{\mathrm{a}}} \\
\text { Controls: } 2.2 \\
{[1.2-3.9]^{\mathrm{a}}}\end{array}$ & $\begin{array}{l}\text { Yes } \\
(p<0.0001)\end{array}$ & FISH & $\begin{array}{l}\text { The } \mathrm{PBC} \text { group had significant higher } \\
\text { rates of monosomy of the } \mathrm{X} \text { chromosome } \\
\text { than the chronic hepatitis } \mathrm{C} \text { or healthy } \\
\text { groups. }\end{array}$ \\
\hline $\begin{array}{l}\text { Invernizzi } \\
\text { et al. [100] }\end{array}$ & 2005 & $\begin{array}{l}\text { SSc } \\
\text { AITD }\end{array}$ & $\begin{array}{l}88 / 100 \\
\text { (Patients: SSc: } 44 \\
\text { [LSSc: } 34, \text { DSSc: } 10] \\
\text { AITD: } 44 \text { [HT: } 32, \\
\text { GD: } 12 \text { ]) }\end{array}$ & $\begin{array}{l}\text { SSc: } 6.2 \pm 0.3 \\
\text { AITD: } 4.3 \pm 0.3 \\
\text { Controls: } 2.9 \pm 0.2\end{array}$ & $\begin{array}{l}\text { Yes (SSc vs. Controls: } \\
p<0.0001 \text {; AITD vs. } \\
\text { Controls: } p<0.0001 \text { ) }\end{array}$ & FISH & $\begin{array}{l}\text { Cells with monosomy X did not have } \\
\text { evidence of the presence of Y chromosome } \\
\text { and thus were not microchimeric. } \\
\text { The rate of monosomy X was found to } \\
\text { increase with age. } \\
\text { No significant differences in monosomy } \\
\text { rates were observed in patients with } \\
\text { different types of SSc and between patients } \\
\text { with GD and HT. }\end{array}$ \\
\hline $\begin{array}{l}\text { Invernizzi } \\
\quad \text { et al. [104] }\end{array}$ & 2007 & SLE & $44 / 73$ & $\begin{array}{l}\text { SLE: } 2.67 \pm 0.22 \\
\text { Controls: } 2.9 \pm 0.17\end{array}$ & No $(p=0.396)$ & FISH & $\begin{array}{l}\text { The rate of } \mathrm{X} \text { monosomy was found to } \\
\text { increase with age both in patients and } \\
\text { healthy subjects. }\end{array}$ \\
\hline $\begin{array}{l}\text { Miozzo } \\
\text { et al. [96] }\end{array}$ & 2007 & PBC & $166 / 266$ & $\begin{array}{l}\text { PBC: } 39 \\
\text { CHC: } 17.5 \\
\text { Healthy Controls: } 24\end{array}$ & Yes $(p=0.006)$ & $\begin{array}{l}\text { QF-PCR analysis } \\
\text { of } 4 \text { X-linked } \\
\text { STRs. } \\
\text { (HUMARA, } \\
\text { DXS8105, } \\
\text { DXS996, P39) }\end{array}$ & $\begin{array}{l}\text { X chromosome loss and X chromosome } \\
\text { inactivation patterns were studied. } \\
\text { Only a small subset of patients and controls } \\
\text { had both a preferential X loss and a skewed } \\
\text { X chromosome inactivation pattern, } \\
\text { suggesting that both processes are } \\
\text { independent. }\end{array}$ \\
\hline
\end{tabular}

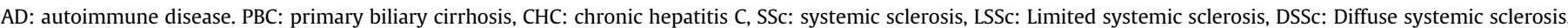

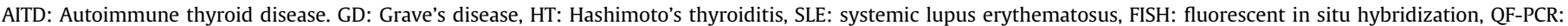
quantitative fluorescent polymerase chain reaction, STRs: short tandem repeats.

${ }^{\text {a }}$ Geometric mean [95\% Confidence Interval].

patients with an HLA-associated disease do not carry the predisposing allele. Although many factors influence this situation, one of the possible explanations that have been raised is the NIMA hypothesis, which states that NIMAs modulate the immune repertoire in the offspring and thus, they might have an influence on protecting or predisposing to ADs $[2,110,111]$. The first attempts to demonstrate this association were done by ten Wolde et al. [110].

Although many of the studies that have addressed the association between NIMA and ADs have failed to find it [110-115], when results were combined, significant differences were found between the frequency of NIMAs, especially HLA-DR4 ${ }^{+}$and Shared Epitope $(\mathrm{SE})^{+}$NIMAs, in RA patients who were negative for DRB $1 * 04$ and SE [114]. However, this could not be duplicated in SLE [112]. Interestingly, another case-control study found that NIMAs of HLA DRB1 alleles that encode the aminoacid sequence DERAA had a protective effect [116]. In this study, the offspring of mothers positive for these alleles had a lower risk of RA (OR $0.25 ; p=0.003$ ) [116]. Akesson et al. found a significant association of HLA-DR4 ${ }^{+}$and HLA-DR3 ${ }^{+}$ NIMAs with type 1 diabetes [117]. Guthrie et al. found the association between HLA-DRA ${ }^{+}$NIMAs to be statistically significant only in females with a younger onset of RA which gives us a possible explanation for conflicting results in studies evaluating NIMAs role in female biased autoimmunity [118].

\section{Microchimerism}

Microchimerism is defined as the movement of hematopoietic stem cells from fetal to maternal circulation or from maternal to fetal circulation (fetal microchimerism and maternal microchimerism respectively) as long as these cells persist $[2,119,120]$. Although considered to be a normal phenomenon, it has been observed that microchimerism might play a role in the development of ADs [120]. It has been postulated that if these cells are targeted as foreign cells they could be implicated in the pathogenesis of ADs [2].
A number of studies have provided clear evidence that microchimerism is associated with SSc although a causal mechanism has not yet been clearly established [121]. SSc is an AD with a strong predilection for women and affects them 3-10 times more than men $[4,82,122,123]$. It has a peak incidence in women after child bearing years and clinical similarities to chronic graft versus host disease [120]. All of this has led researchers to think that microchimerism plays an important role in the pathogenesis of the disease. Nelson et al. and Artlett et al. found that women with SSc have male DNA in their blood and skin lesions more often, and in greater quantities, than unaffected women $(p=0,0007$ and $p<0.001$ respectively) [124,125].

There is some evidence for an association of long term maternal microchimerism in other ADs such as MS and AITD. In a study of twins who are discordant for MS, microchimerism was associated with MS in affected females from monozygotic concordant pairs when compared to both affected $(p=0.020)$ and unaffected $(p=0.025)$ females in monozygotic discordant pairs [126]. In another study of female patients with Hashimoto thyroiditis by Klintschar et al. microchimerism was shown to be significantly more common in Hashimoto patients than in patients suffering from nodular goiter, which suggests a role for microchimerism in the development of Hashimoto's disease. However, the hypothesis that microchimerism was just a bystander in a process triggered by other mechanisms is also possible [127]. Although such findings could not be duplicated in a study of female patients with SLE [128], it does not rule out the possibility that microchimerism may play an important role in the complex pathogenesis of ADs.

Even though microchimerism is expected to be found only in women who have given birth to a son, male DNA has been found in the peripheral blood of nulliparous women. Possible sources proposed for this male DNA include an unrecognized pregnancy with a male fetus or unrecognized male twin, transfer from an older male sibling through the maternal circulation to a female fetus, or sexual intercourse [129]. 
Interestingly, microchimeric cells themselves are not the only ones implicated in the mechanism by which microchimerism influences the development of ADs. Rack et al. found that women with RA had microchimerism of HLA alleles associated with RA - but not with other alleles unrelated to the disease-more frequently and at higher levels compared with healthy female controls [130].

\section{Conclusions}

The more frequent the $\mathrm{AD}$ and the later it appears, the more women are affected. The most convincing explanation of female biased autoimmunity remains the hormonal theory. Estrogens are potent stimulators of autoimmunity and androgens seem to play a protective role in the process. We strongly believe that ADs are complex and multifactorial entities and, although hormone differences may have a strong influence on the predisposition of women to ADs, there is enough evidence to state that genetic factors are important as well. Major understanding of not only the hormonal and genetic factors but also the epigenetic processes related to sex differences in ADs may bring further insight and answers regarding this issue, since ADs constitute a leading cause of death among young and middle-aged women [131]. The majority of studies focus on why women are predisposed to ADs. We propose that additional efforts be made to explore the other side of the story: why are ADs less prevalent in males and could there be a group of protective factors that explains this phenomenon?

\section{Acknowledgements}

We thank all the members of the Center for Autoimmune Diseases research (CREA) for their fruitful discussions. This work was supported by the School of Medicine and Health Sciences of Universidad del Rosario.

\section{References}

[1] Fairweather DL, Frisancho-Kiss S, Rose NR. Sex differences in autoimmune disease from a pathological perspective. Am J Pathol 2008;173:600-9.

[2] Oliver JE, Silman AJ. Why are women predisposed to autoimmune rheumatic diseases? Arthritis Res Ther 2009;11:252-60.

[3] Jacobson DL, Gange SJ, Rose NR, Graham NM. Epidemiology and estimated population burden of selected autoimmune diseases in the United States. Clin Immunol Immunopathol 1997;84:223-43.

[4] Whitacre CC. Sex differences in autoimmune disease. Nat Immunol 2001;2: $777-80$.

[5] Kivity S, Ehrenfeld M. Can we explain the higher prevalence of autoimmune disease in women? Expert Rev Clin Immunol 2010;6:691-4.

[6] Sellner J, Kraus J, Awad A, Milo R, Hemmer B, Stüve O. The increasing incidence and prevalence of female multiple sclerosis-a critical analysis of potential environmental factors. Autoimmun Rev 2011;10:495-502.

[7] Borchers AT, Naguwa SM, Shoenfeld Y, Gershwin ME. The geoepidemiology of systemic lupus erythematosus. Autoimmun Rev 2010;9:A277-87.

[8] Rojas-Villarraga A, Toro CE, Espinosa G, Rodríguez-Velosa Y, Duarte-Rey C, Mantilla RD, et al. Factors influencing polyautoimmunity in systemic lupus erythematosus. Autoimmun Rev 2010;9:229-32.

[9] Amadori A, Zamarchi R, De Silvestro G, Forza G, Cavatton G, Danieli GA, et al. Genetic control of the CD4/CD8 T-cell ratio in humans. Nat Med 1995;1: 1279-83.

[10] Shames RS. Gender differences in the development and function of the immune system. J Adolesc Health 2002;30:59-70.

[11] Cutolo M, Capellino S, Sulli A, Serioli B, Secchi ME, Villaggio B, et al. Estrogens and autoimmune diseases. Ann N Y Acad Sci 2006;1089:538-47.

[12] Lleo A, Battezzati PM, Selmi C, Gershwin ME, Podda M. Is autoimmunity a matter of sex? Autoimmun Rev 2008;7:626-30.

[13] McCarthy M. The" gender gap" in autoimmune disease. Lancet 2000;356: 1088.

[14] Gleicher N, Barad DH. Gender as risk factor for autoimmune diseases J Autoimmun 2007;28:1-6.

[15] Beagley KW, Gockel CM. Regulation of innate and adaptive immunity by the female sex hormones oestradiol and progesterone. FEMS Immunol Med Microbiol 2003;38:13-22.

[16] McMurray RW. Estrogen, prolactin, and autoimmunity: actions and interactions. Int Immunopharmacol 2001;1:995-1008.
[17] Raveche ES, Steinberg AD, Berczi I. Sex hormones in autoimmunity. Pituitary Funct Immun; 1986:283-301.

[18] Rubtsov AV, Rubtsova K, Kappler JW, Marrack P. Genetic and hormonal factors in female-biased autoimmunity. Autoimmun Rev 2010;9:494-8.

[19] Jansson L, Holmdahl R. Estrogen-mediated immunosuppression in autoimmune diseases. Inflamm Res 1998;47:290-301.

[20] Prabhala RH, Wira CR. Sex hormone and IL-6 regulation of antigen presentation in the female reproductive tract mucosal tissues. J Immunol 1995;155:5566-73.

[21] Peeva E, Zouali M. Spotlight on the role of hormonal factors in the emergence of autoreactive B-lymphocytes. Immunol Lett 2005;101:123-43.

[22] Zandman-Goddard G, Peeva E, Shoenfeld Y. Gender and autoimmunity. Autoimmun Rev 2007;6:366-72.

[23] Yacoub Wasef SZ. Gender differences in systemic lupus erythematosus. Gend Med 2004;1:12-7.

[24] Roubinian JR, Talal N, Greenspan JS, Goodman JR, Siiteri PK. Effect of castration and sex hormone treatment on survival, anti-nucleic acid antibodies, and glomerulonephritis in NZB/NZW F1 mice. J Exp Med 1978;147: 1568-83.

[25] Orbach H, Zandman-Goddard G, Amital H, Barak V, Szekanecz Z, Szucs G, et al. Novel biomarkers in autoimmune diseases. Ann N Y Acad Sci 2007; 1109:385-400.

[26] Gutierrez MA, Molina JF, Jara LJ, Cuellar ML, Garcia C, Gutierrez-Ureña S, et al. Prolactin and systemic lupus erythematosus: prolactin secretion by SLE lymphocytes and proliferative (autocrine) activity. Lupus 1995;4:348-52.

[27] Chan RW, Tam LS, Li EK, Lai FM, Chow KM, Lai KB, et al. Inflammatory cytokine gene expression in the urinary sediment of patients with lupus nephritis. Arthritis Rheum 2003;48:1326-31.

[28] Walker SE. Bromocriptine treatment of systemic lupus erythematosus. Lupus $2001 ; 10: 762-8$

[29] Lahita RG, Bradlow HL, Ginzler E, Pang S, New M. Low plasma androgens in women with systemic lupus erythematosus. Arthritis Rheum 1987;30: 241-8.

[30] Sequeira JF, Keser G, Greenstein B, Wheeler MJ, Duarte PC, Khamashta MA, et al. Systemic lupus erythematosus: sex hormones in male patients. Lupus 1993;2:315-7.

[31] Verheul HA, Verveld M, Hoefakker S, Schuurs AH. Effects of ethinylestradiol on the course of spontaneous autoimmune disease in NZB/W and NOD mice. Immunopharmacol Immunotoxicol 1995;17:163-80.

[32] Mavragani CP, Moutsopoulos HM. The geoepidemiology of Sjögren's syndrome. Autoimmun Rev 2010;9:A305-10.

[33] Anaya JM, McGuff HS, Banks PM, Talal N. Clinicopathological factors relating malignant lymphoma with Sjogren's syndrome. Semin Arthritis Rheum 1996;25:337-46.

[34] Baimpa E, Dahabreh IJ, Voulgarelis M, Moutsopoulos HM. Hematologic manifestations and predictors of lymphoma development in primary Sjogren syndrome: clinical and pathophysiologic aspects. Medicine (Baltimore) 2009;88:284-93.

[35] Molina R, Provost TT, Arnett FC, Bias WB, Hochberg MC, Wilson RW, et al. Primary Sjögren's syndrome in men:: clinical, serologic, and immunogenetic features. Am J Med 1986;80:23-31.

[36] Anaya JM, Liu GT, D’Souza E, Ogawa N, Luan X, Talal N. Primary Sjögren's syndrome in men. Ann Rheum Dis 1995;54:748-51.

[37] Drosos AA, Tsiakou EK, Tsifetaki N, Politi EN, Siamopoulou-Mavridou A. Subgroups of primary Sjögren's syndrome. Sjögren's syndrome in male and paediatric Greek patients. Ann Rheum Dis 1997;56:333-5.

[38] Cervera R, Font J, Ramos-Casals M, Garcia-Carrasco M, Rosas J, Morla RM, et al. Primary Sjogren's syndrome in men: clinical and immunological characteristics. Lupus 2000;9:61-4.

[39] Horvath IF, Szodoray P, Zeher M. Primary Sjögren's syndrome in men: clinical and immunological characteristic based on a large cohort of Hungarian patients. Clin Rheumatol 2008;27:1479-83.

[40] Gondran G, Fauchais A, Lambert M, Ly K, Launay D, Queyrel V, et al. Primary Sjögren's syndrome in men. Scand J Rheumatol 2008;37:300-5.

[41] Cutolo M, Sulli A, Capellino S, Villaggio B, Montagna P, Seriolo B, et al. Sex hormones influence on the immune system: basic and clinical aspects in autoimmunity. Lupus 2004;13:635-8.

[42] Castagnetta LA, Carruba G, Granata OM, Stefano R, Miele M, Schmidt M, et al. Increased estrogen formation and estrogen to androgen ratio in the synovial fluid of patients with rheumatoid arthritis. J Rheumatol 2003;30:2597-605.

[43] Cutolo M, Sulli A, Capellino S, Villaggio B, Montagna P, Pizzorni C, et al. Anti TNF and sex hormones. Ann N Y Acad Sci 2006;1069:391-400.

[44] Jacobsson LT, Turesson C, Nilsson JÅ, Petersson IF, Lindqvist E, Saxne T, et al Treatment with TNF blockers and mortality risk in patients with rheumatoid arthritis. Ann Rheum Dis 2007;66:670-5.

[45] Zoli A, Lizzio MM, Ferlisi EM, Massafra V, Mirone L, Barini A, et al. ACTH, cortisol and prolactin in active rheumatoid arthritis. Clin Rheumatol 2002; 21:289-93.

[46] Tobón GJ, Youinou P, Saraux A. The environment, geo-epidemiology, and autoimmune disease: rheumatoid arthritis. Autoimmun Rev 2010;9: A288-92.

[47] Spector TD, Perry LA, Tubb G, Silman AJ, Huskisson EC. Low free testosterone levels in rheumatoid arthritis. Ann Rheum Dis 1988;47:65-8.

[48] Cutolo M, Seriolo B, Villaggio B, Pizzorni C, Craviotto C, Sulli A. Androgens and estrogens modulate the immune and inflammatory responses in rheumatoid arthritis. Ann N Y Acad Sci 2002;966:131-42. 
[49] Chifflot H, Fautrel B, Sordet C, Chatelus E, Sibilia J. Incidence and prevalence of systemic sclerosis: a systematic literature review. Semin Arthritis Rheum 2008;37:223-35.

[50] LeRoy EC, Black C, Fleischmajer R, Jablonska S, Krieg T, Medsger Jr T, et al. Scleroderma (systemic sclerosis): classification, subsets and pathogenesis. J Rheumatol 1988;15:202-5.

[51] Shi-Wen X, Panesar M, Vancheeswaran R, Mason J, Haskard D, Black C, et al. Expression and shedding of intercellular adhesion molecule 1 and lymphocyte function-associated antigen 3 by normal and scleroderma fibroblasts. Effects of interferon-gamma, tumor necrosis alpha and estrogen. Arthritis Rheum 1994;37:1689-97.

[52] Straub RH, Zeuner M, Lock G, Schölmerich J, Lang B. High prolactin and low dehydroepiandrosterone sulphate serum levels in patients with severe systemic sclerosis. Br J Rheumatol 1997;36:426-32.

[53] Nicot A. Gender and sex hormones in multiple sclerosis pathology and therapy. Front Biosci 2009;14:4477-515.

[54] Azar ST, Yamout B. Prolactin secretion is increased in patients with multiple sclerosis. Endocr Res 1999;25:207-14.

[55] Tomassini V, Onesti E, Mainero C, Giugni E, Paolillo A, Salvetti M, et al. Sex hormones modulate brain damage in multiple sclerosis: MRI evidence. J Neurol Neurosurg Psychiatr 2005;76:272-5.

[56] Zandman-Goddard G, Peeva E, Rozman Z, Ben-Zvi I, Langevitz P, Shvartser Y, et al. Sex and gender differences in autoimmune diseases. In: OerteltPrigione S, Regitz-Zagrosek V, editors. Sex and gender aspects in clinical medicine. New York: Springer-Verlag London Limited; 2012. p. 101-24.

[57] Ishimaru N, Arakaki R, Watanabe M, Kobayashi M, Miyazaki K, Hayashi Y. Development of autoimmune exocrinopathy resembling Sjögren's syndrome in estrogen-deficient mice of healthy background. Am J Pathol 2003;163: 1481-90.

[58] Shim GJ, Warner M, Kim HJ, Andersson S, Liu L, Ekman J, et al. Aromatasedeficient mice spontaneously develop a lymphoproliferative autoimmune disease resembling Sjogren's syndrome. Proc Natl Acad Sci U S A 2004;101: 12628-33.

[59] Laroche M, Borg S, Lassoued S, De Lafontan B, Roché H. Joint pain with aromatase inhibitors: abnormal frequency of Sjögren's syndrome. J Rheumatol 2007;34(11):2259-63.

[60] El Miedany YM, Ahmed I, Moustafa H, El Baddini M. Hyperprolactinemia in Sjogren's syndrome: a patient subset or a disease manifestation? Joint Bone Spine 2004;71(3):203-8.

[61] Haga HJ, Rygh T. The prevalence of hyperprolactinemia in patients with primary Sjögren's syndrome. J Rheumatol 1999;26(6):1291-5.

[62] Ostensen M, Aune B, Husby G. Effect of pregnancy and hormonal changes on the activity of rheumatoid arthritis. Scand J Rheumatol 1983;12:69-72.

[63] Clowse ME. Lupus activity in pregnancy. Rheum Dis Clin North Am 2007;33: 237-52.

[64] Andreoli L, Bazzani C, Taraborelli M, Reggia R, Lojacono A, Brucato A, et al. Pregnancy in autoimmune rheumatic diseases: the importance of counselling for old and new challenges. Autoimmun Rev 2010;10:51-4.

[65] Wegmann TG, Lin H, Guilbert L, Mosmann TR. Bidirectional cytokine interactions in the maternal-fetal relationship: is successful pregnancy a TH2 phenomenon? Immunol Today 1993;14:353-6.

[66] Marzi M, Vigano A, Trabattoni D, Salvaggio A, Clerici E, Clerici M. Characterization of type 1 and type 2 cytokine production profile in physiologic and pathologic human pregnancy. Clin Exp Immunol 1996;106:127-33.

[67] Gusdon Jr JP. Fetal and maternal immunoglobulin levels during pregnancy. Am J Obstet Gynecol 1969;103:895-900.

[68] Gladman DD, Tandon A, Ibañez D, Urowitz MB. The effect of lupus nephritis on pregnancy outcome and fetal and maternal complications. J Rheumatol 2010;37:754-8.

[69] Imbasciati E, Tincani A, Gregorini G, Doria A, Moroni G, Cabiddu G, et al. Pregnancy in women with pre-existing lupus nephritis: predictors of fetal and maternal outcome. Nephrol Dial Transplant 2009;24:519-25.

[70] Olsen NJ, Kovacs WJ. Hormones, pregnancy, and rheumatoid arthritis. J Gend Specif Med 2002;5:28-37.

[71] Hazes JM, Coulie PG, Geenen V, Vermeire S, Carbonnel F, Louis E, et al Rheumatoid arthritis and pregnancy: evolution of disease activity and pathophysiological considerations for drug use. Rheumatology (Oxford); 2011 [Epub ahead of print].

[72] Buyon JP. Neonatal lupus. Curr Opin Rheumatol 1996:8:485-90.

[73] Costenbader KH, Feskanich D, Stampfer MJ, Karlson EW. Reproductive and menopausal factors and risk of systemic lupus erythematosus in women. Arthritis Rheum 2007;56:1251-62.

[74] Karlson EW, Mandl LA, Hankinson SE, Grodstein F. Do breast feeding and other reproductive factors influence future risk of rheumatoid arthritis?: Results from the Nurses' health study. Arthritis Rheum 2004; 50:3458-67.

[75] Zorgdrager A, De Keyser J. Menstrually related worsening of symptoms in multiple sclerosis. J Neurol Sci 1997;149:95-7.

[76] Whitacre CC, Reingold SC, O'Looney PA, Blankenhorn E, Brinley F, Collier E, et al. A gender gap in autoimmunity. Science 1999;283:1277-8.

[77] Goemaere S, Ackerman C, Goethals K, De Keyser F, Van der Straeten C, Verbruggen G, et al. Onset of symptoms of rheumatoid arthritis in relation to age, sex and menopausal transition. J Rheumatol 1990;17:1620-2.

[78] Lahita RG. Sex steroids and the rheumatic diseases. Arthritis Rheum 1985; $28: 121-6$.
[79] Arnason BG, Richman DP. Effect of oral contraceptives on experimental demyelinating disease. Arch Neurol 1969;21:103-8.

[80] Liang MH, Karlson EW. Female hormone therapy and the risk of developing or exacerbating systemic lupus erythematosus or rheumatoid arthritis. Proc Assoc Am Physicians 1996;108:25-8.

[81] Petri M. Sex hormones and systemic lupus erythematosus. Lupus 2008;17: 412-5.

[82] Lockshin MD. Sex differences in autoimmune disease. Lupus 2006;15:753-6.

[83] Nalbandian G, Kovats S. Understanding sex biases in immunity: effects of estrogen on the differentiation and function of antigen-presenting cells. Immunol Res 2005;31:91-106

[84] Greer JM, McCombe PA. Role of gender in multiple sclerosis: clinical effects and potential molecular mechanisms. J Neuroimmunol 2011;234:7-18.

[85] Aggarwal R, Namjou B, Li S, D’Souza A, Tsao BP, Bruner BF, et al. Male-only systemic lupus. J Rheumatol 2010;37:1480-7.

[86] Lyon MF. Gene action in the X-chromosome of the mouse (Mus musculus L.) Nature 1961;190:372-3.

[87] Brown CJ. Skewed X-chromosome inactivation: cause or consequence? J Natl Cancer Inst 1999;91:304-5.

[88] Sharp A, Robinson D, Jacobs P. Age- and tissue-specific variation of X chromosome inactivation ratios in normal women. Hum Genet 2000;107:343-9.

[89] Chitnis S, Monteiro J, Glass D, Apatoff B, Salmon J, Concannon P, et al. The role of X-chromosome inactivation in female predisposition to autoimmunity. Arthritis Res 2000;2:399-406.

[90] Uz E, Loubiere LS, Gadi VK, Ozbalkan Z, Stewart J, Nelson JL, et al. Skewed Xchromosome inactivation in scleroderma. Clin Rev Allergy Immunol 2008; 34:352-5.

[91] Uz E, Mustafa C, Topaloglu R, Bilginer Y, Dursun A, Kasapcopur O, et al Increased frequency of extremely skewed $\mathrm{X}$ chromosome inactivation in juvenile idiopathic arthritis. Arthritis Rheum 2009;60:3410-2.

[92] Ozbalkan Z, Bagișlar S, Kiraz S, Akyerli CB, Ozer HT, Yavuz S, et al. Skewed X chromosome inactivation in blood cells of women with scleroderma. Arthritis Rheum 2005;52:1564-70.

[93] Ozcelik T, Uz E, Akyerli CB, Bagislar S, Mustafa CA, Gursoy A, et al. Evidence from autoimmune thyroiditis of skewed X-chromosome inactivation in female predisposition to autoimmunity. Eur J Hum Genet 2006;14:791-7.

[94] Brix TH, Knudsen GP, Kristiansen M, Kyvik KO, Orstavik KH, Hegedus L. High frequency of skewed X-chromosome inactivation in females with autoimmune thyroid disease: a possible explanation for the female predisposition to thyroid autoimmunity. J Clin Endocrinol Metab 2005;90: 5949-53.

[95] Knudsen GP, Harbo HF, Smestad C, Celius EG, Akesson E, Oturai A, et al. $\mathrm{X}$ chromosome inactivation in females with multiple sclerosis. Eur J Neurol 2007; $14: 1392-6$

[96] Miozzo M, Selmi C, Gentilin B, Grati FR, Sirchia S, Oertelt S, et al. Preferential $\mathrm{X}$ chromosome loss but random inactivation characterize primary biliary cirrhosis. Hepatology 2007;46:456-62.

[97] Yin X, Latif R, Tomer Y, Davies TF. Thyroid epigenetics: X chromosome inactivation in patients with autoimmune thyroid disease. Ann N Y Acad Sci 2007;1110:193-200

[98] Chabchoub G, Uz E, Maalej A, Mustafa CA, Rebai A, Mnif M, et al. Analysis of skewed X-chromosome inactivation in females with rheumatoid arthritis and autoimmune thyroid diseases. Arthritis Res Ther 2009;11:R106-13.

[99] Knudsen GP. Gender bias in autoimmune diseases: X chromosome inactivation in women with multiple sclerosis. J Neurol Sci 2009;286:43-6.

[100] Invernizzi P, Miozzo M, Selmi C, Persani L, Battezzati PM, Zuin M, et al. $\mathrm{X}$ chromosome monosomy: a common mechanism for autoimmune diseases. J Immunol 2005;175:575-8.

[101] Invernizzi $P$. The $X$ chromosome in female-predominant autoimmune diseases. Ann N Y Acad Sci 2007;1110:57-64.

[102] Invernizzi P, Pasini S, Selmi C, Gershwin ME, Podda M. Female predominance and X chromosome defects in autoimmune diseases. J Autoimmun 2009;33. $12-6$

[103] Invernizzi P, Miozzo M, Battezzati PM, Bianchi I, Grati FR, Simoni G, et al Frequency of monosomy $\mathrm{X}$ in women with primary biliary cirrhosis. Lancet 2004:363:533-5.

[104] Invernizzi P, Miozzo M, Oertelt-Prigione S, Meroni PL, Persani L, Selmi C, et al. X monosomy in female systemic lupus erythematosus. Ann N Y Acad Sci 2007;1110:84-91.

[105] Selmi C. The $X$ in sex: how autoimmune diseases revolve around sex chromosomes. Best Pract Res Clin Rheumatol 2008;22:913-22.

[106] Ortiz-Neu C, LeRoy EC. The coincidence of Klinefelter's syndrome and systemic lupus erythematosus. Arthritis Rheum 1969;12:241-6.

[107] Gilliland WR, Stashower ME. Klinefelter's syndrome and systemic lupus erythematosus. Clin Exp Rheumatol 2000;18:107-9.

[108] Smith-Bouvier DL, Divekar AA, Sasidhar M, Du S, Tiwari-Woodruff SK, King JK, et al. A role for sex chromosome complement in the female bias in autoimmune disease. J Exp Med 2008;205:1099-108.

[109] Scofield RH, Bruner GR, Namjou B, Kimberly RP, Ramsey-Goldman R, Petri M, et al. Klinefelter's syndrome (47, XXY) in male systemic lupus erythematosus patients: support for the notion of a gene-dose effect from the $\mathrm{X}$ chromosome. Arthritis Rheum 2008;58:2511-7.

[110] ten Wolde $S$, Breedveld FC, de Vries RR, D'Amaro J, Rubenstein P, Schreuder GM, et al. Influence of non-inherited maternal HLA antigens on occurrence of rheumatoid arthritis. Lancet 1993;341:200-2. 
[111] Barrera P, Balsa A, Alves H, Westhovens R, Maenaut K, Cornelis F, et al. Noninherited maternal antigens do not increase the susceptibility for familial rheumatoid arthritis. European Consortium on rheumatoid arthritis families (ECRAF). J Rheumatol 2001;28:968-74.

[112] Bronson PG, Komorowski LK, Ramsay PP, May SL, Noble J, Lane JA, et al. Analysis of maternal-offspring HLA compatibility, parent-of-origin effects, and noninherited maternal antigen effects for HLA-DRB1 in systemic lupus erythematosus. Arthritis Rheum 2010;62:1712-7.

[113] Barrera P, Balsa A, Alves H, Westhovens R, Maenaut K, Cornelis F, et al. Noninherited maternal antigens do not play a role in rheumatoid arthritis susceptibility in Europe. European Consortium on rheumatoid arthritis families. Arthritis Rheum 2000;43:758-64.

[114] Harney S, Newton J, Milicic A, Brown MA, Wordsworth BP. Non-inherited maternal HLA alleles are associated with rheumatoid arthritis. Rheumatology (Oxford) 2003;42:171-4.

[115] van der Horst-Bruinsma IE, Hazes JM, Schreuder GM, Radstake TR, Barrera P, van de Putte LB, et al. Influence of non-inherited maternal HLA-DR antigens on susceptibility to rheumatoid arthritis. Ann Rheum Dis 1998;57:672-5.

[116] Feitsma AL, Worthington J, van der Helm-van Mil AH, Plant D, Thomson W, Ursum J, et al. Protective effect of noninherited maternal HLA-DR antigens on rheumatoid arthritis development. Proc Natl Acad Sci US A 2007;104:19966-70.

[117] Akesson K, Carlsson A, Ivarsson SA, Johansson C, Weidby BM, Ludvigsson J, et al. The non-inherited maternal HLA haplotype affects the risk for type diabetes. Int J Immunogenet 2009;36:1-8.

[118] Guthrie KA, Tishkevich NR, Nelson JL. Non-inherited maternal human leukocyte antigen alleles in susceptibility to familial rheumatoid arthritis. Ann Rheum Dis 2009:68:107-9.

[119] Bianchi DW, Zickwolf GK, Weil GJ, Sylvester S, DeMaria MA. Male fetal progenitor cells persist in maternal blood for as long as 27 years postpartum. Proc Natl Acad Sci U S A 1996;93:705-8.

[120] Evans PC, Lambert N, Maloney S, Furst DE, Moore JM, Nelson JL. Longterm fetal microchimerism in peripheral blood mononuclear cell subsets in healthy women and women with scleroderma. Blood 1999;93: 2033-7.

[121] Willer CJ, Sadovnick AD, Ebers GC. Microchimerism in autoimmunity and transplantation: potential relevance to multiple sclerosis. J Neuroimmunol 2002;126:126-33.

[122] Lockshin MD. Invited review: sex ratio and rheumatic disease. J Appl Physiol 2001;91:2366-73.

[123] Ranque B, Mouthon L. Geoepidemiology of systemic sclerosis. Autoimmun Rev 2010;9:A311-8.

[124] Artlett CM, Smith JB, Jimenez SA. Identification of fetal DNA and cells in skin lesions from women with systemic sclerosis. N Engl J Med 1998;338:1186-91.

[125] Nelson JL, Furst DE, Maloney S, Gooley T, Evans PC, Smith A, et al. Microchimerism and HLA-compatible relationships of pregnancy in scleroderma. Lancet 1998;351:559-62.

[126] Willer CJ, Herrera BM, Morrison KM, Sadovnick AD, Ebers GC. Association between microchimerism and multiple sclerosis in Canadian twins. J Neuroimmunol 2006;179:145-51.

[127] Klintschar M, Schwaiger P, Mannweiler S, Regauer S, Kleiber M. Evidence of fetal microchimerism in Hashimoto's thyroiditis. J Clin Endocrinol Metab 2001;86:2494-8.

[128] Mosca M, Curcio M, Lapi S, Valentini G, D’Angelo S, Rizzo G, et al. Correlations of Y chromosome microchimerism with disease activity in patients with SLE: analysis of preliminary data. Ann Rheum Dis 2003;62:651-4.

[129] Lambert NC, Pang JM, Yan Z, Erickson TD, Stevens AM, Furst DE, et al. Male microchimerism in women with systemic sclerosis and healthy women who have never given birth to a son. Ann Rheum Dis 2005;64:845-8.

[130] Rak JM, Maestroni L, Balandraud N, Guis S, Boudinet H, Guzian MC, et al. Transfer of the shared epitope through microchimerism in women with rheumatoid arthritis. Arthritis Rheum 2009;60:73-80.

[131] Walsh SJ, Rau LM. Autoimmune diseases: a leading cause of death among young and middle-aged women in the United states. Am J Public Health 2000;90:1463-6. 